\title{
IMPLEMENTASI KEBIJAKAN TATA KELOLA PEMERINTAHAN DAERAH DENGAN SEMANGAT EFOURIA DEMOKRASI LOKAL
}

\author{
Jaelan Usman \\ Fakultas Ilmu Sosial dan Ilmu Politik Universitas Muhammadiyah Makassar \\ Jl. Sultan Alauddin No. 259 Makassar 90221 \\ Telp. 0411 - 866972 ext. 107 Fax. 0411 - 865588
}

\section{ABSTRAK}

$\mathbf{P}$

erjalan reformasi kurang lebih 13 tahun pasca pemerintahan rezim Orde Baru 32 tahun; menimbulkan beberapa pertanyaan kritis yang harus dijawab dalam konteks "Tata Kelola Pemerintahan Daerah, dengan semangat Efouria Demokrasi Lokal". Beberapa pertanyaan kritis dimaksud, timbul dari praktek desentralisasi dan otonomi daerah, antara lain: Sejauh mana desentralisasi dan otonomi daerah mendorong tumbuhnya demokrasi lokal yang kokoh dan beradab? Bagaimana nasib perkembangan demokrasi lokal pasca Pemilihan Umum Legislatif dan Pemilihan Presiden 2009? Desentralisasi, secara teoretis, merupakan upaya untuk membawa negara lebih dekat dengan masyarakat lokal serta mendorong tumbuhnya tata pemerintahan lokal yang lebih demokratis. Dengan kata lain, tanpa diikuti dengan demokrasi lokal, desentralisasi dan otonomi daerah tidak lebih hanya memindahkan sentralisasi dan korupsi dari pusat ke daerah. Tata pemerintahan lokal yang demokratis, mengedepankan prinsip pemerintahan "dari" masyarakat, dikelola secara akuntabel dan transparan "oleh" masyarakat dan dimanfaatkan secara responsive "untuk" kepentingan masyarakat luas.

Kata Kunci : Tata Kelola Pemerintahan Daerah, Efouria Demokrasi Lokal.

\section{A. PENDAHULUAN}

Perjalanan sistem desentralisasi di Indonesia jika dirunut sepanjang sejarah perjalanan bangsa ini cukup panjang dan berliku. Perubahan politik di tahun 1990-an menjadi arus balik perjalanan bangsa Indonesia yang membawa beberapa dampak positif. Perubahan tersebut di antaranya mengubah tata hubungan antara Pemerintah Pusat dan Daerah ke arah yang lebih demokratis dengan memperbesar porsi desentralisasi. Dengan perubahan sistem pemerintahan tersebut, otomatis berbagai pranata pendukung sistem yang selama ini bersifat sentralistik juga mengalami perubahan.

Sistem pemerintahan desentralisasi sebenarnya telah digagas oleh para pendiri negara ini dengan menempatkan satu pasal dalam UUD 1945 (pasal 18). Implementasi 
pasal tersebut selalu menimbulkan persoalan sejak tahun-tahun awal kemerdekaan. Pergulatan mencari makna kebangsaan yang dipandang sebagai identitas sekunder, selalu menghadapi persoalan identitas primer berupa kuatnya solidaritas etnik, agama, adat dan bahasa serta tradisi lokal. Faktor-faktor ini pula yang menyebabkan timbulnya pemberontakan kedaerahan selain faktor ketidakadilan dalam pembagian sumberdaya ekonomi antara Pusat dan Daerah (Maryanov, 1958; Harvey, 1983).

Sejak tahun 1945 itu pula, Pemerintah Pusat memandang pluralitas secara ambivalen. Di satu sisi mempromosikan Bhinneka Tunggal Ika sebagai semboyan resmi negara, di sisi lain menerapkan kebijakan sentralisasi karena kebhinekaan dilihat sebagai ancaman disintegrasi. Selama masa kepemimpinan Soekarno berlangsung 16 kali pergantian kabinet. Yang menarik dari proses tersebut adalah program-program kabinet yang menempatkan "desentralisasi", "otonomi daerah" atau "memperbaiki hubungan PusatDaerah" sebagai prioritas. Meskipun usaha tersebut mengalami kegagalan, tetapi menunjukkan betapa penting dan mendesak mewujudkan hubungan Pusat-Daerah yang seimbang dan proporsional. Perpaduan antara tuntutan Daerah dan kehendak Pusat inilah yang terus menerus dicari. Oleh sebab itu sepanjang kepemimpinannya berlangsung 4 kali perubahan undang-undang pemerintahan daerah.

Di bawah undang-undang no. 1/1945 dilakukan pembentukan daerah-daerah otonom yang masih terbatas di Jawa. Jangkauan undang-undang ini sangat terbatas, mengingat sebagai negara baru masih mencari-cari bentuk, termasuk susunan pemerintahan daerah yang pluralistik sebagai warisan penjajahan. Belanda menerapkan dua sistem yang berbeda, yaitu indirect rule untuk Jawa dan direct rule untuk luar Jawa. Dampak kedua sistem ini cukup besar dalam susunan pemerintahan lokal. Jika di Jawa otoritas tradisional dalam batas-batas tertentu masih kuat, maka di luar jawa kesatuan sosial dalam bentuk suku, wilayah, kepulauan saling memotong (cross cutting). Gejala ini di satu sisi menumbuhkan kuatnya identitas primer (primordialisme) di sisi lain berlangsung besaran (magnitude) oleh proses ekonomi kapitalistik yang mengintegrasikan ekonomi luar jawa secara langsung dengan pasar internasional.

Undang-undang No. 22/1948 memberi ruang gerak daerah yang lebih luas dibanding sebelumnya. Guna menghidupkan pemerintahan lokal dan kesatuan sosial, dibentuk daerah tingkat III yang satuannya dapat berupa desa atau satuan yang setingkat. Akibatnya kontrol Pusat terhadap Daerah berkurang tajam. Tidak mengherankan di bawah undang-undang tersebut berlangsung berbagai pemberontakan daerah (DI, TII, PERMESTA, RMS), selain pemberontakan PKI di Madiun. Guna mencegah menguatnya daerahisme, provinsialisme dan memperkuat kontrol Pusat, dikeluarkan undang-undang No. 1/1957. Di bawah undang-undang baru ini kandungan keseimbangan antara.

Pusat dan Daerah lebih mengemuka. Meski-pun bukan produk DPR hasil pemilu 1955 secara penuh, hubungan Pusat-Daerah lebih demokratis. Tetapi kemacetankemacetan segera terjadi, yang penyebab utamanya adalah pembagian hasil hutan, pertambangan dan perkebunan yang lebih berpihak ke Pusat.

Romantisme agama turut mempengaruhi ketegangan Pusat-Daerah, sehingga undangundang tersebut tidak dapat diimplementasikan secara optimal. Selain itu konflik ideologi partai dan politisasi massa untuk keperluan partai-partai, menguras energi dan tidak terdapat kesempatan untuk mengoptimalkan undang-undang tersebut. Ketegangan antar partai, khususnya antara PKI dan kekuatan oponennya, melahirkan undang-undang No. 18/1965. Aturan ini tidak banyak mewarnai hubungan Pusat-Daerah, sebab kekacauan segera terjadi. Di bawah kepemimpinan Soeharto, sentralisasi setengah hatinya Soekarno dikonkritkan.

Soeharto tanpa ragu-ragu melihat keanekaragaman budaya, geopolitik kepulauan dan kemajemukan ideologi sebagai ancaman persatuan dan kesatuan bangsa. Integrasi nasional dalam visi Soeharto harus 
dimulai dari integrasi wilayah (keutuhan wilayah) dan merasuk ke integrasi bangsa (Soeharto, 1989). Dalam visi demikian, perbedaan ideologi tidak dapat ditoleransi. Itulah sebabnya mengapa kepemimpinan Soeharto anti partai, anti kemajemukan ideologi dan menyatukan ideologi dalam asas tunggal.

Kekhawatiran akan lahirnya daerahisme dan provinsialisme, dipertegas dengan membatasi masa jabatan kepala daerah dan mekanisme pemilihan. Kepala Daerah tidak sepenuhnya dipilih oleh Dewan. Secara formal mekanismenya adalah perpaduan antara kehendak Daerah (mengusulkan tiga nama) dan kehendak Pusat (menentukan/memilih satu dari tiga yang diusulkan Dewan). Tetapi secara substantif, Kepala Daerah adalah orang Pusat yang ditempatkan di daerah. Selain didesain untuk mengendalikan Daerah, undang-undang No. 5/1974 tidak memberi ruang gerak yang memadai bagi tokoh-tokoh Daerah untuk membangun kekuatan dengan identitas Daerah.

Pembunuhan massal yang berlangsung pertengahan tahun 1960-an, merupakan kendala struktural bagi kekuatan masyarakat termasuk kekuatan-kekuatan di Daerah untuk melakukan tawar menawar dengan Pusat. Menguatnya sentralisasi di awal kepemimpinan Soeharto sesungguhnya memiliki argumen empirik yang kuat, seperti konflik ideologi global, geopolitik Indonesia yang berbentuk kepulauan dan pluralitas kultural. Latar belakang sebagai seorang militer yang sebelumnya terlibat secara aktif dalam memadamkan pemberontakan daerah dan sebagai orang Jawa yang tidak menempuh pendidikan tinggi, tidak memiliki referensi lain selain kebudayaan jawa. Dalam konsep kebudayaan jawa, kekuasaan itu utuh dan konkrit (Anderson, 1985), sehingga menerapkan desentralisasi berarti mengurangi kekuasaan pemimpin Pusat. Pertimbangan empiris lainnya adalah kebutuhan akan kemajuan ekonomi yang mendesak. Syarat untuk itu adalah stabilitas sosial politik yang dimaknai sebagai terwujudnya keamanan dan ketertiban masyarakat. Berdasarkan pertimbangan- pertimbangan tersebut, dilakukan penataan struktur politik di awal tahun 1970-an.

\section{B. LANDASAN TEORITIS}

Landasan teoritis tentang hubungan Pusat de-ngan Daerah, penataan tersebut mengkristal pada pembentukan sistem pemerintahan daerah yang tanggap terhadap komando Pusat (Mas'oed, 1989). Jenjang pemerintahan didesain bertingkat dengan kepemimpinan berlatar belakang militer untuk memastikan dipatuhinya perintah Jenderal berbintang empat kepada jenderal berbintang dua di provinsi dan kepada para kolonel di kabupaten atau kota. Serentak dengan itu, birokrasi digunakan sebagai kekuatan utama perencana dan pelaksana. Pilihan itu untuk menjamin rantai komando dari Jakarta ke pelosok tanah air, mengingat hanya birokrasi kekuatan yang tersebar ke pelosok tanah air. Namun, setelah pembangunan menunjukkan bukti-bukti konkrit seperti meningkatnya usia harapan hidup dari 44 tahun (1965) menjadi 59 tahun (1995), meningkatnya angka partisipasi sekolah dasar yang mencapai 100 persen sejak tahun 1993, meningkatnya pendapatan perkapita masyarakat dari negara miskin (1965) ke negara berpendapatan menengah (1995) dan menurunnya angka kemiskinan dari 45 persen penduduk Indonesia (1965) menjadi 13,5 persen (1995), ternyata format hubungan Pusat dengan Daerah tidak mengalami perubahan. Padahal dalam teori pembangunan, perubahan-perubahan yang mengarah ke semakin meningkatnya kesejahteraan masyarakat, diperlukan ruang yang lebih terbuka untuk memberi wadah partisipasi masyarakat (Huntington, 1968). Kegagalan membangun institusi yang mampu memberi tempat partisipasi masyarakat, akan menghancurkan hasil-hasil pembangunan yang telah dicapai. Ruang dan institusi yang dimaksud adalah partisipasi, transparansi, keadilan dan kompetisi (demokratisasi).

Secara politik, desentralisasi merupakan langkah menuju demokratisasi. Dengan desentralisasi, pemerintah lebih dekat dengan rakyat, sehingga kehadiran pemerintah lebih 
dirasakan oleh rakyat dan keterlibatan rakyat dalam perencanaan, pelaksanaan dan pengawasan pembangunan dan pemerintahan semakin nyata. Secara sosial, desentralisasi akan mendorong masyarakat ke arah swakelola dengan memfungsikan pranata sosial yang merupakan social capital dalam menyelesaikan persoalan-persoalan yang mereka hadapi. Dengan pranata yang telah internalized, mekanisme penyelesaian mereka pandang lebih efektif, efisien dan adil. Sedangkan secara ekonomi, desentralisasi diyakini dapat mencegah eksploitasi Pusat terhadap daerah, menumbuhkan inovasi masyarakat dan mendorong motivasi masyarakat untuk lebih produktif.

Secara administratif akan mampu meningkatkan kemampuan daerah dalam melakukan perencanaan, pengorganisasian, meningkatkan akuntabilitas atau pertanggung jawaban publik. Baik Undang-Undang No. 22/ 1999 maupun amandemennya UU No. 32/ 2004 tentang Perintahan Daerah menganut pemikiran seperti itu. Bahwa peningkatan kualitas kehidupan masyarakat, kualitas pelayanan pemerintah dan optimalisasi peran serta masyarakat dalam pembangunan, merupakan trimatra yang mendasari lahirnya UU No. 22/1999 dan amandemennya yaitu UU No. 32/2004.

Gagasan pemerintah sebagai fasilitator dalam pembangunan masyarakat, masih jauh dari harapan, jika memperhatikan kinerja birokrasi selama beberapa tahun terakhir. Selain format ideal bagi keberadaan birokrasi di berbagai level pemerintahan belum menemukan bentuknya, tarik menarik antara pemerintah daerah propinsi dengan kabupaten dan dengan Pusat, masih mewarnai penyelenggaraan pemerintahan di Indonesia.

Selain itu, kecenderungan semua level pemerintahan untuk menjalankan semua fungsi pelayanan juga masih dominan, sehingga kecenderungan masyarakat sebagai obyek penerima pelayanan juga masih menonjol. Intervensi pemerintah di masa yang lalu telah menimbulkan masalah rendahnya kapabilitas dan efektivitas pemerintah daerah dalam mendorong proses pembangunan dan demokrasi. Arahan dan statutory requirement yang terlalu besar dari Pemerintah Pusat menyebabkan inisiatif dan prakarsa daerah cenderung mati, sehingga pemerintah daerah seringkali menjadikan pemenuhan peraturan sebagai tujuan, dan bukan sebagai alat untuk meningkatkan pelayanan kepada masyarakat (Mardiasmo, 2002).

Besarnya arahan dari Pusat itu didasarkan atas pertimbangan menjamin stabilitas nasional dan kondisi sumberdaya manusia di daerah. Hal ini dapat dipahami, sebab konteks sosial dan politik dirumuskannya UU No. 5/ 1974 adalah penegakan stabilitas nasional dan pemberantasan kemiskinan serta keterbelakangan masyarakat.

Tetapi dalam jangka panjang, sentralisasi seperti itu telah menimbulkan rendahnya akuntabilitas, memperlambat pembangunan infrastruktur sosial, rendahnya tingkat pengembalian proyek-proyek publik, serta memperlambat pengembangan kelembagaan sosial ekonomi di daerah (Bastin dan Smoke, 1992). Apalagi sejak tahun 1990-an berlangsung new game di fora internasional di mana negara tidak akan mampu lagi sebagai pemain tunggal dalam menghadapi hyper competitive. Pemerintah akan terlalu besar untuk menyelesaikan masalah kecil dan terlalu kecil untuk dapat menyelesaikan masalah yang dihadapi oleh masyarakat.

Secara tegas dapat dikatakan bahwa, desentralisasi tidak semata-mata untuk membentuk pemerintahan daerah yang menjalankan kekuasaan dan menghasilkan kebijakan, tetapi yang lebih penting adalah untuk membangkitkan kompetensi warga terhadap urusannya sendiri, komunitas dan pemerintah lokal. Dengan demikian, secara akademik banyak pelajaran dan argumen yang kuat bahwa desentralisasi menumbuhkan modal sosial dan tradisi kewargaan di tingkat lokal. Partisipasi demokratis warga telah membiakkan komitmen warga yang luas maupun hubungan-hubungan horizontal: kepercayaan (trust), toleransi, kerja-sama, dan solidaritas yang membentuk apa yang disebut komunitas sipil (civic community). Indikatorindikator civic engagement solidaritas sosial dan partisipasi massal yang merentang luas 
pada gilirannya berkorelasi tinggi dengan kinerja pembangunan ekonomi dan kualitas kehidupan demokrasi.

Pada dasarnya, desentralisasi bertujuan membangun partisipasi masyarakat dan mengundang keterlibatan publik seluasluasnya dalam proses perencanaan, implementasi dan evaluasi pembangunan yang dijalankan. Untuk itu, desentralisasi memberikan ruang yang lebih luas kepada daerah untuk secara demokratis mengatur pemerintahannya sendiri sebagai manifestasi dari cita-cita sistem desentralisasi. Tetapi, pelaksanaan sistem ini mendapatkan tantangan yang cukup besar. Kendala-kendala tersebut diantaranya adalah (1) mindset atau mentalitas aparat birokrasi yang belum berubah; (2) hubungan antara institusi pusat dengan daerah; (3) sumber daya manusia yang terbatas; (4) pertarungan kepentingan yang berorientasi pada perebutan kekuasaan, penguasaan aset dan adanya semacam gejala powershift syndrom yang menghinggapi aparat pemerintah; dan (5) keinginan pemerintah untuk menjadikan desa sebagai unit politik di samping unit sosial budaya dimana desa memiliki tatanan sosial budaya yang otonom.

Pada kenyataannya, mindset atau mentalitas menjadi kendala yang cukup besar bagi pelaksanaan tata pemerintahan yang baru ini. Selama kurang lebih 5 tahun pelaksanaan otonomi daerah (2000-2005), timbul berbagai persoalan yang disebabkan karena pola pikir dan mentalitas yang belum berubah. Di masa lalu, sistem sentralistik mengebiri inisiatif lokal dan menempatkan pemerintah pusat sebagai penguasa yang memiliki wewenang sangat besar atas berbagai bentuk kebijakan pembangunan. Keseragaman dan kepatuhan daerah terhadap pusat menjadi kata kunci sekaligus sebagai mainstream dan ideologi pembangunan yang dijalankan. Karenanya, pada masa itu kritik menjadi sesuatu yang tabu dan jika terlontar akan sangat mudah untuk dijerat secara hukum sebagai tindakan subversi atau anti pemerintah.

Setidaknya selama 32 tahun rezim orde baru proses ini berlangsung secara terus- menerus sehingga tidak mengherankan jika mentalitas birokrasi pada akhirnya mengikuti pola tersebut. Konflik menjadi sesuatu yang tabu dan keberagaman dipandang sebagai ancaman dan sumber disintegrasi bangsa. Pola pemerintahan yang diterapkan dalam struktur kekuasaan dikenal sebagai pemerintahan yang harmoni tanpa gejolak dengan mengembangkan ideologi 'Triple $S$ ' yaitu; Serasi, Selaras dan Seimbang.

Pada akhirnya terbentuklah subordinasi hubungan antara pemerintah pusat-daerah dengan kekuasaan sepenuhnya berada di pemerintah pusat. Subordinasi yang berlangsung lama menjadi penyebab ketergantungan daerah sangat tinggi. Maka, pada saat terjadi perubahan sistem yang sentralistik menjadi desentralisasi, daerah kurang memiliki kesiapan terutama dalam hal mengambil inisiatif dalam menentukan kebijakan. Tentu saja desentralisasi dan otonomi daerah mengandung berbagai konsekuensi, diantaranya adalah mentalitas dan kapasitas pemerintah daerah yang harus memadai sehingga dapat menjamin pelaksanaan desentralisasi secara maksimal.

Kewenangan yang cukup besar berada di tangan pemerintah daerah, berarti pemerintah daerah memiliki keleluasaan sekaligus tanggung jawab yang lebih besar daripada sistem yang berlangsung sebelumnya. Hanya saja, kendala sumber daya manusia hingga saat ini masih membayangi-bayangi kinerja aparat pemerintah daerah.

Maka, tidak mengherankan jika pada saat ini, muncul persoalan-persoalan seperti batas wilayah, ketidakharmonisan hubungan antar institusi pusat-daerah, berbagai konflik horizontal yang dipengaruhi oleh konfigurasi etnis atau sentimen primordial dan berbagai kebijakan untuk meningkatkan pendapatan daerah yang cenderung memberatkan rakyat.

Dalam situasi yang serba terkungkung selama lebih dari tiga puluh tahun, tiba-tiba daerah memiliki kewenangan yang sedemikian besar. Implikasi dari pelimpahan wewenang tersebut di sebagian daerah menimbulkan munculnya kembali chauvinisme kedaerahan seperti munculnya kekuatankekuatan kelompok aristokrasi dalam politik 
lokal, kekuatan yang di masa Orde Baru ditekan.

Kepentingan yang berorientasi kekuasaan politis dan penguasaan aset daerah menjadi persoalan yang kerap mencuat dalam masa transisi pelaksanaan desentralisasi dan otonomi daerah. Konflik kepentingan berupa penguasaan aset seringkali menjadi kerikil dalam perjalanan proses desentralisasi. Gejala etno-sentrisme mulai muncul pada saat meledaknya kerusuhan berlatar belakang etnis di beberapa wilayah seperti Sampit, Poso, Ambon dan di beberapa daerah pemekaran.

Bahkan pada saat dipilihnya kepala daerah berdasarkan UU No. 22/1999 di tahun 2000, isu PAD (Putra Asli Daerah) merebak. Tuntutan dipilihnya gubernur, bupati serta walikota Putra Asli Daerah bahkan masuk ke dalam tata tertib DPRD. Ini menunjukkan bahwa isu putra daerah merupakan isu yang paling sentisitf dan berpotensi mengganggu hubungan baik antara pendatang tetapi telah lama berdomisili di tempat tersebut dan mengenal secara baik daerah tersebut. Orangorang yang potensial dan berkualitas tetapi bukan putra daerah akan cenderung tersingkir dalam proses politik di daerah dan hanya akan mendapat peran pinggiran saja.

\section{HASIL ANALISIS DAN PEMBAHASAN}

Selama 32 tahun rezim Orde Baru dan 13 tahun Reformasi, sentralisasi dan desentralisasi politik di Indonesia telah secara luas mentransformasikan kultur politik elite dalam suatu arah yang demokratis, meskipun masih jauh dari harapan dan kepuasan semua pihak. Pembentukan pemerintahan regional, yang kemudian mendapatkan sejumlah kekuasaan otonom yang signifikan dan kontrol atas sumberdaya lokal, menghasilkan suatu tipe perpolitikan yang secara ideologis tidak terlalu terpolarisasi, lebih moderat, toleran, pragmatis, lebih fleksibel dan suatu penerimaan mutual yang lebih besar di antara hampir semua partai'.

Secara berangsur-angsur warga mengidentifikasi diri dengan level pemerintahan lokal dan bahkan lebih menghargainya ketimbang pemerintahan nasional. Selain itu, harus dipahami bahwa desentralisasi dan demokratisasi lokal memiliki potensi besar untuk merangsang pertumbuhan organisasi-organisasi, serta jaringan masyarakat sipil (civil society).

Arena kehidupan komunitas dan lokal lebih menawarkan cakupan terbesar bagi organisasi-organisasi independen untuk membentuk dan mempengaruhi kebijakan. Pada level lokal, rintangan-rintangan sosial dan organisasional terhadap aksi kolektif lebih rendah maupun problem-problem yang menuntut perhatian dari layanan sosial sampai transportasi serta lingkungan yang berdampak langsung pada kualitas hidup masyarakat. Keterlibatan langsung warga dalam penyelenggaraan layanan publik pada level lokal menghasilkan suatu peluang penting untuk memperkuat keterampilan para warga secara individual dan akumulasi modal sosial, seraya membuat penyampaian layanan publik lebih accountable.

Sorotan terhadap reformasi sejak 1998 telah membangkitkan desentralisasi dan demokrasi lokal, yang menggerogoti struktur politik yang hirarkhis, sentralistik, feodalistik dan otoriter. Locus politik telah bergeser dari pusat ke daerah, dari sentralisasi ke desentralisasi, dari bureaucratic government ke party government, dan dari executive heavy ke legislative heavy. Tetapi, seperti akan diuraikan di bawah, demokrasi lokal yang berlangsung masih sebatas efouria, bukan sebagai proses konsolidasi menuju demokrasi lokal yang kokoh, beradab dan terpercaya. Efouria demokrasi lokal sangat bermasalah, dan tetap akan bermasalah sampai pasca pemilu 2009 karena fondasi yang sangat rapuh. Praktik demokrasi lokal selama ini lebih banyak diwarnai dengan sejumlah efouria yang masih sangat rapuh.

Pertama, efouria demokrasi elektoral. Masyarakat Indonesia, kini, tengah terjangkit demam perayaan demokrasi elektoral. Ada kesan kuat bahwa demokrasi hanya terfokus pada pemilihan, sebuah perayaan politik yang sarat dengan pesta, kompetisi, sensasi, mobilisasi, money politics, intrik, caci-maki, perdukunan, dan seterusnya. Di zaman dulu, penentuan kepala daerah berlangsung secara 
tertutup dan memperoleh pengawasan yang ketat dari Jakarta. Hanya tentara dan birokrat yang punya peluang untuk menduduki jabatan kepala daerah. DPRD dalam posisi yang sangat lemah, tidak mempunyai otoritas untuk menentukan pilihan mereka.

Sekarang proses pemilihan lebih terbuka, yang membuka kesempatan bagi hadirnya aktor-aktor baru di luar tentara dan birokrat. DPRD mempunyai kuasa penuh untuk menentukan pilihan mereka terhadap kepala daerah. Tetapi proses dan hasil pemilihan kepala daerah tidak lebih baik daripada sebelumnya. Setiap pemilihan selalu diwarnai dengan permainan politik uang, kekerasan, mobilisasi massa dan seterusnya. Proses yang buruk itu mesti membuahkan hasil yang buruk. Tidak sedikit kepala daerah yang bermasalah dan korup untuk mengembalikan modal yang telah dimainkan melalui politik uang.

Rakyat kecewa, tetapi setiap pemilihan politik uang tetap bermain. Dari kasus-kasus ini dapat dipahami bahwa, demokrasi lokal bukan sekadar proses elektoral, atau proses pemilihan kepala daerah, tetapi yang lebih penting adalah relasi yang demokratis seharihari antara pemerintah daerah dengan warga masyarakat. Akuntabilitas, transparansi dan responsivitas pemerintah dae-rah jauh lebih penting dari sekadar proses elektoral. Proses elektoral sebenarnya merupakan langkah awal untuk menghasilkan pemimpin lokal yang memiliki visi dan komitmen serius pada akuntabilitas, transparansi dan responsivitas pemerintah daerah. Tetapi kalau isu-isu ini dikalahkan oleh jumlah massa, popularitas, apalagi oleh politik uang, maka demokrasi lokal akan hancur dan rakyat terus-menerus akan kecewa.

Kedua, efouria semangat keasilan (nativisme). Di setiap daerah bergelora isu "putera daerah" terutama ketika terjadi pemilihan kepala daerah. Masyarakat lokal sekarang secara keras berani menentang kehadiran calon-calon yang bukan putera daerah untuk menduduki jabatan kepala daerah. Di masa Orde Baru, istilah itu memang sangat berguna untuk menentang intervensi Jakarta atau menolak calon titipan dari Jakarta.
Tetapi yang berkembang sekarang, istilah putera daerah tidak mempunyai otentisitas yang kuat, karena istilah itu cenderung hanya sebagai pasport politik untuk menjustifikasi kedudukan seseorang, tanpa melihat visi dan kualifikasinya. Setelah "putera daerah" itu berkuasa, ternyata bertindak menyimpang dari prinsip-prinsip akuntabilitas, transparansi, dan responsivitas.

Ketiga, efouria parlemen lokal. Di bawah UU No. 22/1999, DPRD sangat powerful ketimbang kepala daerah. Publik berharap, bahwa DPRD yang powerful itu menjadi modal politik untuk memainkan check and balances dengan baik di hadapan kepala daerah, sehingga pemerintahan daerah bisa berjalan secara akuntabel, transparan dan responsif. Tetapi DPRD yang kuat itu justru menimbulkan banyak masalah: DPRD menjadi oligarki baru yang korup, berkapasitas rendah, tidak bertanggungjawab, tidak peka pada aspirasi rakyat, lebih mengutamakan kepentingan sendiri. DPRD, kata publik, bukan sebagai panggilan hidup dan komit-men untuk berjuang, melainkan seperti lowongan kerja untuk mencari nafkah dan kedudukan. Akibatnya, rakyat kecewa dan tidak percaya pada DPRD. Sayangnya, besok dalam pemilihan umum 2004, rakyat tetap akan memilih lagi calon-calon DPRD. Besok kecewa lagi.

Keempat, efouria kepialangan politik. Otonomi daerah memang telah member kesempatan yang terbuka bagi hadirnya aktor-aktor politik baru, termasuk para broker politik. Latar belakang mereka sangat bermacam-macam: bisa kyai, akademisi, mahasiswa, LSM, pengusaha, tokoh adat, tokoh masyarakat, preman, dan seterusnya. Setiap ada pemilihan kepala daerah, para broker politik itu menjadi pemain yang penting, entah dalam membuat opini publik atau mengerahkan massa, dengan tujuan untuk mencari kedudukan atau kekayaan. Mengikuti pendapat para filsuf zaman Yunani Kuno, massa yang digerakkan oleh para broker tersebut bukan rakyat, warga atau publik yang sejati, melainkan gerombolan massa (the mob) yang sebenarnya merusak demokrasi lokal, misalnya dengan cara permainan politik uang maupun kekerasan. 
Kelima, efouria NGO lokal. Era reformasi dan otonomi daerah telah melahirkan begitu banyak NGO lokal yang bersifat instan. Sebagian besar NGO lokal lahir bukan dalam konteks gerakan sosial dan jaringan sosial yang luas, tetapi sebagai bentuk respons atas proyek-proyek pemerintah sejak JPS maupun sebagai bentuk "gerakan politik" untuk memainkan kepialangan politik. NGO lokal yang berorientasi proyek selalu kasak-kusuk mencari proyek, entah melalui lobby atau melontarkan kritik keras kepada Pemda agar mereka memperoleh proyek. NGO "gerakan politik" sangat rajin melakukan kasak-kusuk menjadi broker politik dalam pemilihan kepala daerah, pemilihan DPRD maupun pejabat teras di daerah.

Keenam, efouria protes sosial atau pembangkangan sipil. Sejak Soeharto jatuh di tahun 1998, protes sosial (pembangkangan sipil) mengalami perluasan, sebagai senjata untuk menggerakkan reformasi politik. Protes sosial atau pembang-kangan sipil memang merupakan kekuatan alternatif bagi civil society untuk melawan penguasa. Tetapi harap diingat, bahwa protes sosial yang terjadi di Indonesia selama ini lebih bersifat kegembiraan sesaat atau sebagai partisipasi ad hoc yang hanya sangat efektif untuk menjatuhkan penguasa otoriter bermasalah, tetapi tidak efektif untuk membangun demokrasi lokal. Membangun demokrasi lokal tentu membutuhkan penguatan gerakan sosial masyarakat sipil dan partisipasi warga masyarakat secara berkelanjutan.

Keenam efouria di atas memberi gambaran yang suram tentang demokrasi lokal, yang tampaknya masih akan berlanjut, terutama terhadap pemilihan kepala daerah yang dipilih secara langsung sejak tahun 2005, yang kian menyuburkan efouria politik. Efouria adalah kegembiraan sesaat, yaitu proses politik hanya berlangsung dalam situasi darurat jangka pendek. Kegembiraan jangka pendek itu tidak bakal membuahkan demokrasi lokal yang kokoh dan berkelanjutan, kalau tidak dikatan gagal; kecuali hanya membuahkan kekecewaan dan ketidakpercayaan. Efouria akan come and go berbarengan dengan pesta politik. Eforia akan berubah menjadi kekecewaan bila pesta sudah usai, tetapi ia akan datang lagi kalau pesta bakal digelar kembali.

\section{KESIMPULAN}

Bertitik tolok dari uraian terdahulu tentang kebijakan tata kelola pemerintahan daerah, dengan semangat efouria demokrasi lokal yang merupakan lingkaran setan yang tidak pernah terselesaikan secara tuntas. Hal ini karena fondasi yang betul-betul rapuh, terutama beberapa indikator yang disoroti dapat ditarik kesimpulan sebagai berikut :

1. Perubahan belum sempurna dari floatingmass society menuju civil society. Sekarang Indonesia masih dalam sekuen masyarakat transisi, atau sering disebut sebagai masspolitics society. Proses politik dan demokrasi di Indonesia lebih banyak ditentukan oleh kuantitas massa yang dimobilisir (mobilized mass), bukan oleh visi, kebajikan maupun organized mass.

2. Umumnya daerah di Indonesia mewarisi kuatnya tradisi politik feodal, otoritarian, birokratis dan sentralistik. Tradisi yang relatif kekal ini membentuk paradigma kolot para elite dalam mengelola kekuasaan, mengatur rakyat dan menguasai sumberdaya ekonomi. Para gubernur misalnya, sangat berang karena kekuasaannya atas bupati-bupati dipreteli oleh UU No. 32/2004. Gubernur sekarang tidak bisa lagi memerintah bupati, memanipulasi DAU, atau mengutip pajakpajak daerah seperti dulu. Bahkan sekadar undangan pun diabaikan oleh bupati. Karena itu para gubernur menuntut agar otonomi daerah diletakkan di provinsi atau meminta agar kekuasaan dan kewenangan mereka dipulihkan seperti sedia kala. Sementara, bupati sekarang mempunyai kekuasaan dan kewenangan yang sangat besar. Mereka di atas angin, ibarat raja-raja kecil yang secara leluasa bisa menguasai sumberdaya politik dan ekonomi daerah. "Otonomi daerah berhenti di tangan saya", demikian ungkap arogan seorang bupati ketika menanggapi masalah otonomi desa. 
3. Seorang Bupati bukan pemimpin yang betul-betul mengayomi masyarakat, melainkan hanya seorang pejabat yang pekerjaannya adalah tandatangan, marahmarah dan jalan-jalan", demikian ungkap seorang pegawai yang minta identitasnya dirahasiakan. DPRD kabupaten dan/atau kota sekarang mempunyai kekuasaan dan kewenangan yang luar biasa, karena mereka gunakan untuk menekan bupati/walikota dengan senjata ampuh Laporan Pertanggungjawaban. Namun, ulah anggota DPRD yang tidak bertanggungjawab itu dengan mudah bisa dipadamkan oleh bupati/walikota setelah memperoleh kucuran dana, proyek, dan fasilitas.

4. Paradigma 'K-3' (kekuasaan, kewenangan dan kekayaan) dipegang betul oleh para pemegang jabatan politik. Mereka tidak mempunyai visi bagaimana memanfaatkan kekuasaan untuk memperjuangkan nilai, melainkan hanya berorientasi bagaimana mencari dan mempertahankan kekuasaan. Setiap penguasa, dari presiden hingga bupati dan kepala desa, selalu berupaya keras agar tetap menduduki jabatan yang kedua kalinya. Ini tidak lain hanya untuk memelihara status quo. Kalau dinalar secara sehat, setiap penguasa sebenarnya tidak mempunyai alasan lagi untuk menduduki jabatan yang kedua kalinya. Kalau mereka menampilkan visi, publik bisa bertanya: lalu ngapain selama lima tahun berkuasa.

5. Fragmentasi masyarakat sipil dan modal sosial. Organisasi masyarakat sipil dan modal sosial yang kian semarak, memang tidak tunggal. Di balik kemajuan dalam organisasi nonpemerintah, juga menyaksikan banyak sisi paradoksal dalam modal sosial. Secara horizontal kemajemukan masyarakat menyajikan konflik ketimbang pluralisme dan kohesivitas. Ruang publik civil society memang menghadirkan wacana dan gerakan demokratisasi yang semarak, tetapi polarisasi ideologis dan kepentingan adalah sajian yang jauh lebih menonjol. Inilah yang penulis sebut sebagai fragmented social capital. Gerakan demokratisasi yang didorong oleh aktor-aktor civil society harus berhadapan dengan praktik-praktik kekerasan yang dimainkan oleh elemen masyarakat lainnya. Bahkan gerakan demokratisasi yang terus maju tidak didukung oleh elemen-elemen partai oposisi yang pro perubahan.

6. Baik di tingkat pusat maupun di daerah, partai politik bukanlah pendukung otentik demok-ratisasi melainkan sebagai bagian dari pemeliharaan status quo yang harus direformasi. Di banyak daerah, gerakan demokratisasi civil society terus bergelora menentang "raja-raja kecil" yang bermasalah, tetapi gerakan itu dengan mudah dilumpuhkan oleh para preman bayaran maupun paramiliter yang dipelihara oleh partai politik. Semua ini memang tidak mengehentikan gerakan demokratisasi meski harus dibayar dengan risiko kekerasan, tetapi gerakan civil society terseok-seok, tunggang-langgang dan menghadapi anomalie yang serius.

\section{DAFTAR PUSTAKA}

Elisabeth, Adriana, dkk, 2004, Pemetaan Peran dan Kepentingan Para Aktor dalam Konflik di Papua, Lembaga Ilmu Pengetahuan Indonesia (LIPI), Jakarta.

Fakih, Mansour. 1996. Masyarakat Sipil untuk Transformasi Sosial. Pergolakan Ideologi LSM Indonesia. Yogyakarta: Pustaka Pelajar.

Hagul, Peter, ed. 1992. Pembangunan Desa dan Lembaga Swadaya Masyarakat, Rajawali Press, Jakarta.

Johnson, Doyle Paul, 1986, Teori Sosiologi Klasik dan Modern, PT Gramedia, Jakarta.

Haba, John, dkk, 2003, Konflik di Kawasan Ilegak Logging di Kalimantan Tengah, Jakarta, LIPI. Kasiepo, Manuel, 1987, Dari Perpolitikan Birokratik ke Korporatisme Negara: Birokrasi dan Politik di Indonesia Era Orde Baru, 
Jurnal Ilmu Politik 2, Gramedia bekerjasama dengan Asosiasi Ilmu Politik Indonesia (AIPI), Jakarta.

Ndara, Talizuduhu, 1986, Birokrasi dan Pembangunan, Dominasi atau Alat Demokratisasi: Suatu Telaah Pendahuluan, Jurnal Ilmu Politik 1, Gramedia bekerjasama dengan Asosiasi Ilmu Politik Indonesia (AIPI), Jakarta.

Piliang, Indra J, dkk (ed.), 2003, Otonomi Daerah, Evaluasi dan Proyeksi, Yayasan Harkat Bangsa bekerjasama dengan Partnership Governance Reform in Indonesia, Jakarta.

Ratnawati, Tri (ed.), 2000, Otonomi Daerah dalam Perspektif Lokal, Kasus Jawa Timur, Sumatera Barat dan Nusa Tenggara Timur, Puslitbang Politik dan Kewilayahan LIPI, Jakarta.

Zulkarnaen, Iskandar, dkk, 2003, Potensi Konflik di Daerah Pertambangan, Kasus Pongkor dan Cilandak, Jakarta, LIPI. Clark, John.1995. NGO dan Pembangunan Demokrasi. Tiara Wacana, Yogyakarta.

Huntington, Samuel P dan Joan Nelson. 1992. Partisipasi Politikdi Negara Berkembang.
Rineka Cipta, Jakarta.

Isdijoso, Brahmantio, et. al. 2001. Prospek Penerapan Budget Tranparency dalam Pelaksanaan otonomi Daerah dan Desentralisasi Fiskal Di Daerah Kabupaten dan Kota di Indonesia. Center for Economic and Social Studies, Jakarta.

Jeff Haynes, Demokrasi dan Masyarakat Sipil di Dunia Ketiga. 2000. Gerakan Politik Baru Kaum Terpinggir. Yayasan Obor Indonesia, Jakarta.

Kuncoro, Mudrajad. 2004. Otonomi dan Pembangunan Daerah; Reformasi, Perencanaan, Strategi, dan Peluang, Erlangga, Jakarta.

Pilliang, Indra J. et. al. 2003. Otonomi Daerah; Evaluasi dan Proyeksi. Yayasan Harkat Bangsa Bekerjasama dengan Partnership for Governance Reform in Indonesi, Jakarta.

Prodjodikoro, Wirjono. 1981. Asas-asas Ilmu Negara dan Politik. PT Eresco, Bandung.

Sarundajang. 1999. Arus Balik Kekuasaan Pusat ke Daerah. Pustaka Sinar Harapan, Jakarta. 